\title{
Гуманітарне насильство, або Критика американського імперіалізму
}

Atanasoski, Neda. Humanitarian Violence: The US Deployment of Diversity. University of Minnesota Press, 2013.

$\mathrm{P}$

езонуючи з популярними сьогодні студіями «Американської імперії», книга Неди Етенесоскі «Гуманітарне насильство» $є$ передусім критикою сучасного американського імперіалізму. Зокрема Етенесоскі стверджує, що американський імперіалізм експлуатує гуманітарну етику задля досягнення глобальної експансії. Відтак під виглядом боротьби за демократичні цінності та права і свободи Сполучені Штати розгортають політику світового панування.

Побудована хронологічно, книга розглядає найбільші американські воєнні кампанії після Другої світової війни. На прикладах В'єтнамської, Афганської та Балканських воєн 1990-х років Етенесоскі стверджує, що американські інтервенції «вибілювалися» через зображення інших регіонів як місць крайнього насильства, варварства та відсталості, які Америка покликана гуманізувати. Авторка вдало поєднує різноманітні приклади з літератури, фотожурналістики та кінематографу, аби показати формування ідеалізованого образу США як універсального носія демократії, свободи та ліберальних цінностей.

У книжці «Гуманітарне насильство» показано, що американська імперська риторика гуманітаризму, яку авторка називає «постсоціалістичним імперіалізмом», $є$ черговою реінкарнацією старого колоніального словника прогресу і просвітництва «відсталих» регіонів. Так само, як в XIX і на початку XX століття західний імперіалізм декларував «благородну» мету цивілізувати «недорозвинуті» регіони, США після Холодної війни пояснювали свою агресивну зовнішню політику бажанням зупинити насильство і порушення прав людини у світі. На думку Етенесоскі, «гуманітарне насильство» як новітня форма західного імперіалізму виникло у відповідь на нові геополітичні реалії, що постали після завершення Холодної війни. У цей час «комуністичне зло» перестало бути основним ворогом американської демократії. США почали шукали 
нові расовані «місця пітьми», щоб принести туди світоч ліберальної демократії і капіталізму.

Одним із таких «місць пітьми» став В’єтнам. Як стверджує Етенососкі, В’єтнамська війна сприяла майбутньому утвердженню нового гуманітарного імперіалізму. Попри воєнну невдачу США, символічну перемогу у В’єтнамі здобули американські нові медіа. Ця перемога полягала у приголомшливій відкритості американських медій до зображення звірств армії США. Для прикладу, Етенососкі показує, що документування насильства відомим американським фотографом Еді Адамсом та іншими кореспондентами стали інструментами «реанімації демократії». Авторка наголошує, що надалі Америка не боялася використовувати спрямовану на неї критику в'єтнамської політики, щоб довести силу і унікальність американського імперського проекту. Адже тільки справді демократична країна була здатна зіткнутися із власним періодом «пітьми» у В'єтнамі та публічно викрити державні злочини.

Втім, для Етенесоскі критика американського імперіалізму є також «співучасницею» імперського проекту, яка підживлює його. Авторка, зокрема, підкреслює, що демонстрація співчуття та співпереживання йшли пліч-о-пліч з об'єктивацією і расуванням місцевого населення. Справді, місцеві громади були лише тлом для демонстрації американської публічної спокути за злочинне насильство у В'єтнамі. До того ж, безпосередня критика американської політики у В’єтнамі відтворювала старі колоніальні тропи. На прикладі документальної стрічки «Серця пітьми» Елеанор Кополи про зйомки «Апокаліпсису сьогодні» Етенесоскі демонструє, як стрічка, що критикує американський колоніалізм, $\epsilon$ водночас його продуктом. Відомо, що Френсіс Копола знімав «Апокаліпсис сьогодні» не у B'єтнамі, а на Філіппінах, у колишній американській колонії. Відтак у фільмі увесь регіон Південно-Східної Азії перетворювався на узагальнений позаісторичний простір насильства. Окрім того, зйомки були черговим прикладом колоніальної експлуатаційної економіки. Попри шалений бюджет фільму, задіяне у зйомках місцеве населення отримувало мінімальну оплату. Відтак, Етенесоскі показує парадоксальність культурної критики американського імперіалізму: здатність викривати хиби імперського проекту не підважує імперіалізм, а навпаки, реанімує його і допомагає формувати його етичне обличчя. Інакше кажучи, антиімперська критика творить образ США як здатної до саморефлексії моральної імперії.

Після В’єтнамської війни новим етапом застосування гуманітарної риторики для утвердження американського глобального домінування стала війна в Афганістані. Американські медіа позиціонували воєнну кампанію в Афганістані як вимушений захід з метою захисту релігійних свобод місцевого населення, якому загрожував безбожний радянський імперіалізм. Підтримувані США моджахеди змальовувалися борцями за свободу проти репресивного радянського режиму. Однак, із завер- 
шенням Холодної війни зникла необхідність демонізувати Радянський Союз; натомість після теракту 11 вересня виникла потреба переозначити афганську війну. На прикладі вже канонічного фото Стіва МакКарі «Афганська дівчина» (1985), Етенесоскі показує, що під час радянсько-афганської війни фото мало викликати співчуття до афганських біженців, але в умовах американської інтервенції в Афганістан 2000-х років воно перетворилося на символ боротьби за права жінок. Відтак, антирадянська риторика змінилася критикою афганських моджахедів, які тепер стали втіленням «тоталітарного і деспотичного зла». В обох випадках гуманітарна риторика, як наголошує авторка, була ключовою в обгрунтуванні американської інтервенції.

Воєнні кампанії у В'єтнамі та Афганістані заклали основи імперської американської гуманітарної етики, але повністю вона проявилася під час Балканських воєн 1990-х. Етенесоскі звертає увагу, що після Холодної війни Балкани стали метафорою позаісторичного простору насильства, де відбуваються расові, етнічні й цивілізаційні протистояння «просвітленого» Заходу з «доісторичним диким Сходом». Апелюючи до блокбастера «Ван Гельсинґ», авторка наголошує, що демонізація Балкан як місця домодерного вампірського насильства дозволила військам НАТО здійснити воєнну інтервенцію з порушенням міжнародного права. Проте на офіційному рівні ці нелегальні дії НАТО було подано як морально виправдані, а тому легітимні. Балканські війни стали прецедентом, що закріпив за Сполученими Штатами право приймати рішення всупереч міжнародному законодавству. Для Етенесоскі воєнне втручання НАТО стало ключовим свідченням постсоціалістичного імперського домінування Америки, яка отримала безапеляційне право судити і карати, порушуючи наявні правові норми.

Врешті, у книжці «Гуманітарне насильство» йдеться про те, що повоєнний Міжнародний трибунал щодо колишньої Югославії став ще одним кроком до утвердження нового ліберального порядку. Дослідження демонструє, що діяльність трибуналу перетворила Балкани на місце, де «Захід» вправлявся у створенні нових стандартів «постсоціалістичної моралі та гуманності». На прикладі феміністичної боротьби за визнання зґвалтування знаряддям війни та геноциду авторка показує, як феміністичний правовий активізм проклав дорогу до встановлення глобальної версії американської моральної етики. Етенесоскі критикує західних феміністок за вкрай вузьке бачення встановлення справедливості на Балканах: «Створюючи єдиний наратив про спільну людяність, що заснована на секулярних, мультикультурних і феміністичних цінностях, трибунал змушує населення маркованих насильством регіонів [Балкан], задекларувати свою віру в принципи і процедури трибуналу, якщо вони хочуть знову отримати визнання світової спільноти як правдивого людяного регіону» (курсив мій - О.Д.). Таким чином, хоч трибунал став важливим прецедентом завдяки виокремленню сексуального 
i ґендерно-зумовленого насильства як злочинів проти людяності, авторка критикує його за узаконення західної моральної етики як єдино прийнятної для врегулювання конфлікту та повоєнної нормалізації на Балканах.

Попри гостру критику американського імперіалізму, праця «Гуманітарне насильство» не стверджує, ніби США є імперією зла. Книга $\epsilon$ радше активним закликом до переосмислення американської зовнішньої політики, що ніяк не позбудеться старих західних імперських тропів. Етенесоскі наголошує на важливості формулювання нової гуманітарної етики, яка не об'єктивуватиме і не дегуманізуватиме регіони поза Заходом.

Книжка «Гуманітарне насильство» стимулюватиме не тільки тих читачів і читачок, які прагнуть долучитися до концептуалізації «альтернативних формулювань для справедливості». 3 огляду на розмаїття представлених сюжетів і багатоманітність методологічних підходів, книга буде цікавою також тим, хто хоче більше дізнатися, як витворюються культурні змісти на перетині політики, насильства, культури і медій. Також дослідження Етенесоскі є чудовою нагодою критично переосмислити роль сучасної гуманітарної політики й обміркувати, як ми можемо демонструвати емпатію і турботу, не вдаючись до об’єктивації відмінних людей і культур. 